
WANDERLEY JOSÉ FEDERIGHI

\section{AS RESTRIÇÕES AOS DIREITOS DO PRÓDIGO NO DIREITO CIVIL BRASILEIRO}

TESE DE DOUTORADO

PROFESSOR ORIENTADOR CARLOS ALBERTO DABUS MALUF

Faculdade de Direito da Universidade de São Paulo São Paulo 2018 


\section{WANDERLEY JOSÉ FEDERIGHI}

\section{AS RESTRIÇÕES AOS DIREITOS DO PRÓDIGO NO DIREITO CIVIL BRASILEIRO}

Tese apresentada à Banca Examinadora do Programa de Pós-Graduação em Direito, da Faculdade de Direito da Universidade de São Paulo, como exigência parcial para obtenção do título de Doutor em Direito Civil, sob a orientação do Professor Titular Doutor Carlos Alberto Dabus Maluf.

Faculdade de Direito da Universidade de São Paulo São Paulo 
Membros da Banca Examinadora

Prof. Carlos Alberto Dabus Maluf (Orientador) 


\section{AGRADECIMENTOS}

A meu orientador, professor Carlos Alberto Dabus Maluf, pela sua fidalguia, prontidão, inegável cultura jurídica, apoio e, sobretudo, pela honra de ter me distinguido como um de seus orientandos no curso de Doutorado na Faculdade de Direito da USP.

Ao preclaro amigo Rui Geraldo Camargo Viana, meu orientador no curso de Mestrado, e que continuou comigo a caminhada para a conclusão deste trabalho.

A minhas caras assistentes, Camila Prado Sérgio e Natália Veneziano Gravina Di Iorio, cuja colaboração foi preciosa para que eu pudesse findar esta longa e espinhosa caminhada.

A Deus, por ter me permitido chegar ao final de tal jornada. 


\section{DEDICATÓRIA}

À minha família, do passado e do presente - o único, o verdadeiro tesouro de um homem, sem o qual ele jamais poderá viver. 


\section{EPÍGRAFE}

“A sorte nos dá a mesa suntuosa; a temperança nos dá a mesa em que nada falta".

(Demócrito).

“O único propósito com o qual se legitima o poder sobre algum membro de uma comunidade civilizada, contra a sua vontade, é evitar danos aos demais".

(John Stuart Mill, Sobre a Liberdade). 


\section{RESUMO}

O pródigo, apesar de ser lembrado em boa parte da legislação dos países mais modernos do mundo atual, normalmente não recebe a atenção devida por parte do nosso legislador. No Brasil, desde a entrada em vigor do Código Civil de 1916, até os dias atuais, com o Código Civil de 2002, poucos artigos são destinados especificamente a ele, não indo além de qualificá-lo como relativamente incapaz, estabelecer a necessidade de sua interdição e fixar quais são os atos jurídicos que ele não poderá praticar.

Entendendo que o tema das restrições aos direitos do pródigo apresenta várias nuances, buscou-se analisar as mesmas, iniciando pela sua conceituação (léxica, jurídica e médico-psiquiátrica) para, em seguida, efetuar-se anotações sobre o tema no direito précodificado e no direito estrangeiro, examinando-se legislações que tanto se assemelham como discrepam da nossa.

Também procurou-se examinar a legislação brasileira referente ao tema, iniciando pelas Ordenações, passando pela Consolidação das Leis Civis de Teixeira de Freitas para chegar-se aos dois Códigos Civis, de 1916 e 2002, além de uma imprescindível análise dos dois Códigos de Processo Civil (de 1973 e 2015); estes, no tocante à ação de interdição do pródigo, seus efeitos e eventual levantamento.

Não foram esquecidas questões correlatas, como a da Teoria do Negócio Jurídico e o quanto ela tem de relações com o tema aqui desenvolvido; a possibilidade de introdução do instituto da inabilitação em nosso ordenamento jurídico, instituto este existente em outros países e aplicado aos relativamente incapazes, além de questões diversas, entre as quais a entrada em vigor do Estatuto da Pessoa com Deficiência (EPD) e o quanto houve de reflexos no nosso tema com a introdução dessa lei em nosso referido ordenamento jurídico.

Por fim, foram apresentadas nossas conclusões, bem como sugestões, visando a uma aplicação mais racional, prática e justa do direito, no que diz respeito ao tema estudado. 


\begin{abstract}
Albeit being referred to in the law systems of several of the most modern countries of the contemporary world, the prodigal person usually doesn't get due attention from our legislators. In Brazil, since the 1916 Civil Code started ruling, until current days, with the 2002 Civil Code, few articles are specifically reserved for him, and they don't go beyond qualifying him as relatively incompetent, stablishing the need for his guardianship and specifying the juridical acts that he can't practice on his own.

Figuring that the subject of the restrictions to the rights of the prodigal person shows several different shades, the author's intent was to analyze these shades, starting with the definition of the prodigal person (lexical, legal and psychiatric); after that, to make notes on the theme on pre-codifyied law and on foreign law, examining law systems that are similar and different from ours.

The author also sought to examine brazilian laws that regard the subject, starting with the Ordenações; proceeding with the Consolidação das Leis Civis (Consolidation of Civil Laws) by Teixeira de Freitas, to end on the two Civil Codes, from 1916 and 2002, besides an indispensable analysis of the two Civil Procedure Codes (from 1973 and 2015); these two, regarding the custody procedures, their effects and eventual ending of said custody.
\end{abstract}

Correlate questions were not forgotten, such as the Theory of the Juristic Acts and how much it has relations with the subject here developed; the Consumer's Code and the issue of the "super-indebtedness"; the possibility of the introduction of the inability in our law system, which exists in other countries, applied to those relatively incompetent, besides several issues, among which the new Statute of the Person with Defficiency and its reflexes in our legal system.

For last, the author brings out his conclusions, as well as his suggestions, aiming for a more rational, practical and fair application of the law, concerning the subject in study. 


\section{SINTESI}

Il prodigo, malgrado constare di buona parte della legislazione delle paesi piú moderni del mondo contemporaneo, in normalità non riceve la attenzione dovuta del nostro legislatore. In Brasile, dal momento che è entrato em vigore il Codice Civile di 1916, fino ai giorni attuali, con il Codice Civile di 2002, pocchi articoli sono assegnati specialmente a lui, limitandosi a qualificarlo come relativamente incapace, disporre la necessità della sua interdizione e fissare le atti giuridiche che non può praticare.

Pensando che il soggetto delle restrizioni ai diritti del prodigo presenta vari sfumature, ci è cercato di annalizzare le stessi, cominciando per la sua definizione (lessica, giuridica e psichiatrica), per, al seguito, effetuare appunti sul tema nel diritto pre-codificato e nel diritto straniero, esaminandosi legislazioni che sono assomigliati e in discrepanza della nostra.

Anche si è cercato di analizzare la legislazione brasiliana concernente al tema, cominciando dalle Ordinamenti, pasando a la Consolidazione delle Legge Civili di Teixeira de Freitas, arrivando alle due Codici Civili, di 1916 e 2002, oltre una imprescindibile analisi dei due Codici di Processo Civile (di 1973 e 2015); questi, concernenti a la azione di interdizione del prodigo, suoi effetti ed eventuale fine.

Non sono dimenticati questioni corrispondenti, come la Teoria del Negozio Giuridico e le sue relazioni con il soggetto qui sviluppato; il Codigo del Consumatore e la questione del "superindebitare"; la possibilità de la introduzione del istituto della inabilitazione nella nostra legislazione, existente in altri paesi ed impiegato ai relativamente incapaci, oltre di questioni diverse, tra le quale la entrata in vigore dello Statuto della Persona con Deficienza (EPD) e li reflessi nel nostro soggetto con la introduzione di questa legge nel nostro sistema.

In fine, sono stati presentati le nostre conclusioni e suggerimenti, con il obiettivo di una applicazione piú razionale, pratica e giusta del diritto a rispetto del tema studiato. 


\section{SUMÁRIO}

INTRODUÇÃO 1

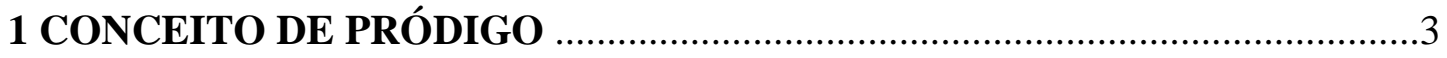

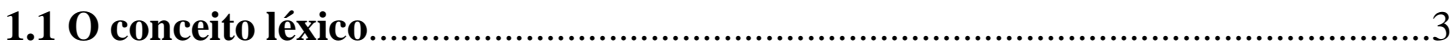

$1.2 \mathrm{O}$ conceito jurídico e os elementos da prodigalidade ........................................4

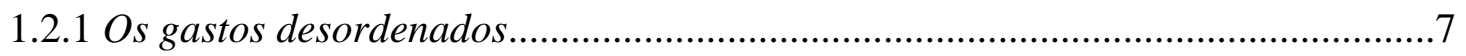

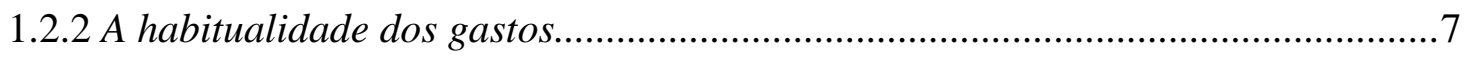

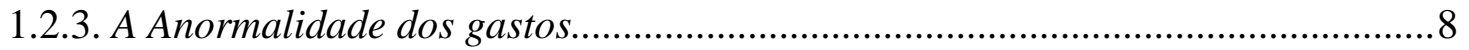

1.2.4. Dilapidação de parte importante do patrimônio da pessoa ..................................8

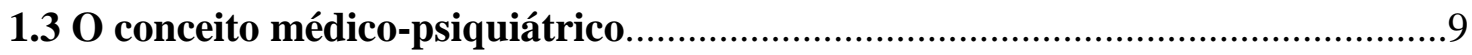

2 ANOTAÇÕES SOBRE O TEMA NO DIREITO PRÉ-CODIFICADO ..............19

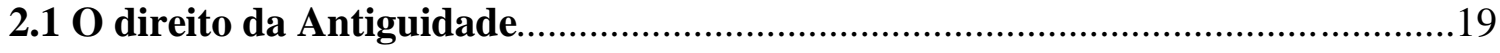

2.1.1 O Egito e a Mesopotâmia...................................................................................19

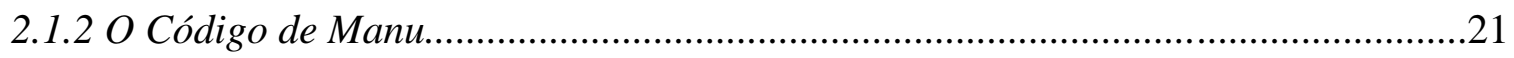

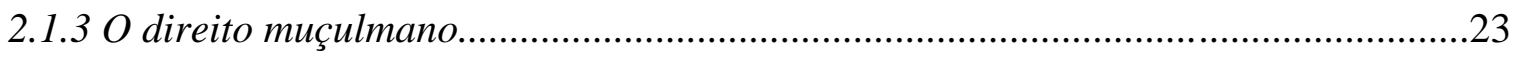

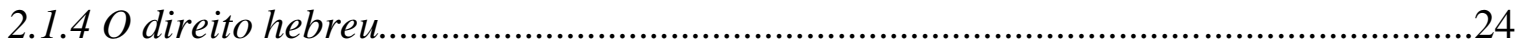

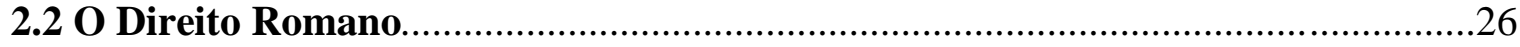

2.2.1 A antiga Roma (ou direito pré-clássico ou arcaico)...............................................28

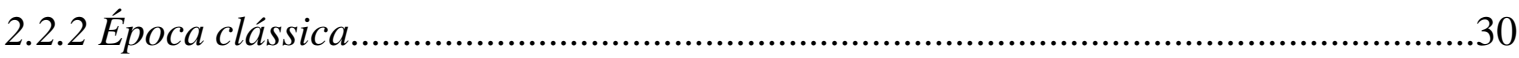

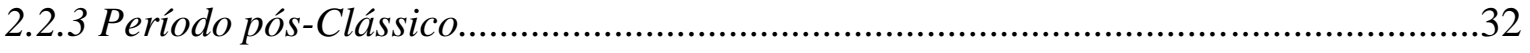

3 BREVES CONSIDERAÇÕES SOBRE O TEMA NO DIREITO

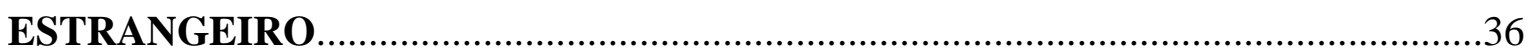

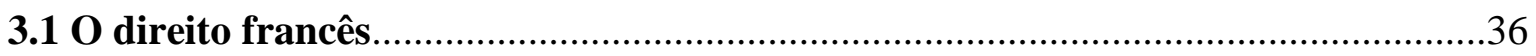

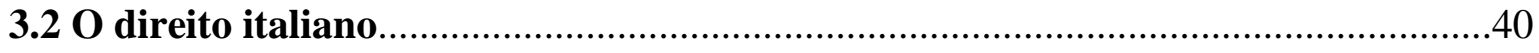

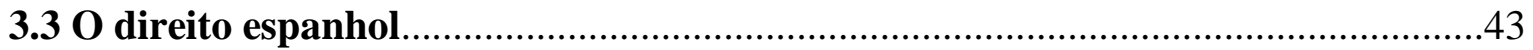

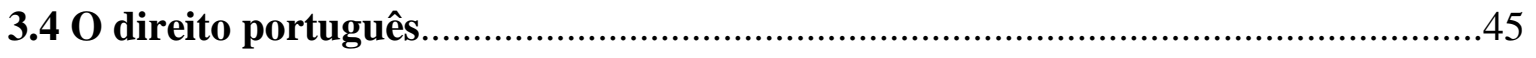

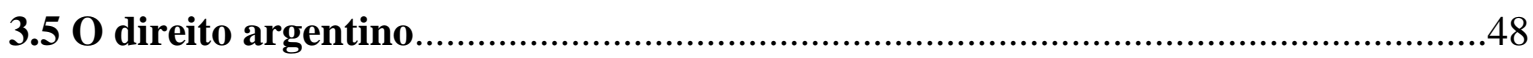




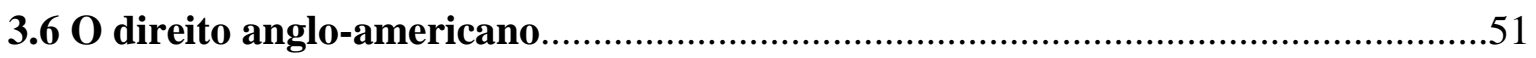

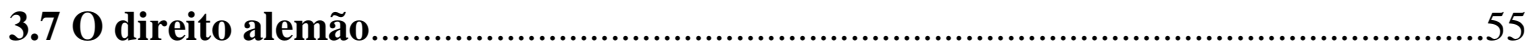

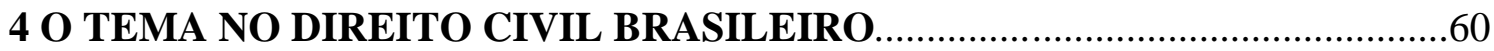

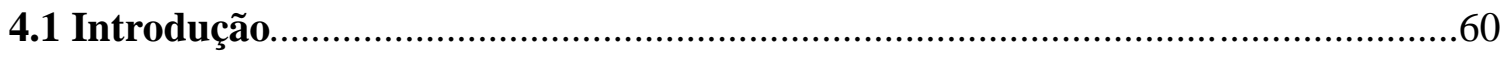

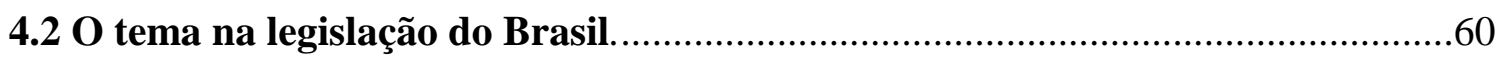

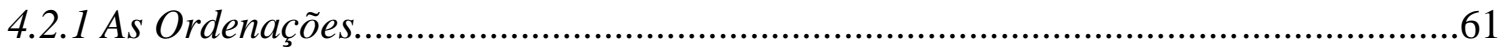

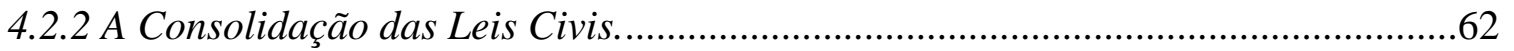

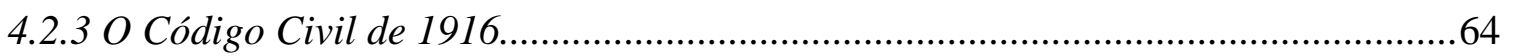

4.2.3.1 A capacidade civil da pessoa física.................................................................66

4.2.3.2 A incapacidade relativa. Limites à capacidade civil........................................67

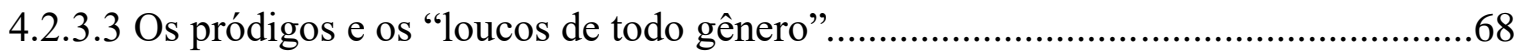

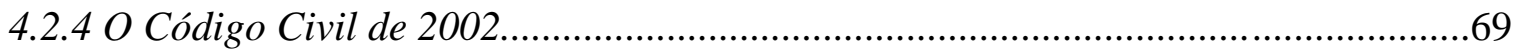

4.2.4.1 As modificações verificadas no novo Código.....................................................69

4.2.4.2 O EPD e o novo CPC: normas em conflito.........................................................73

5 A INTERDIÇÃO DO PRÓDIGO E A AÇÃO CORRESPONDENTE ..................75

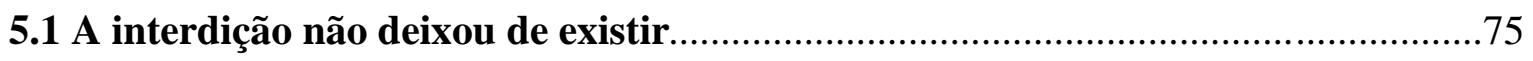

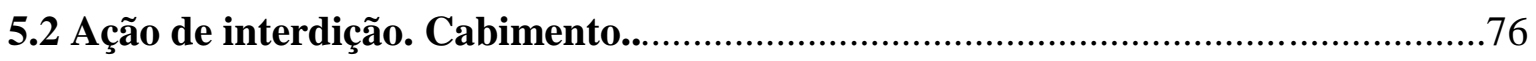

5.3 Legitimidade ativa. O Código Civil de 1916 e o Código de Processo Civil de

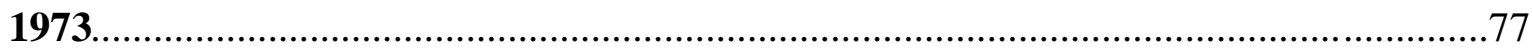

5.4 O CC de 2002, o novo CPC e o Estatuto da Pessoa com Deficiência.......................78

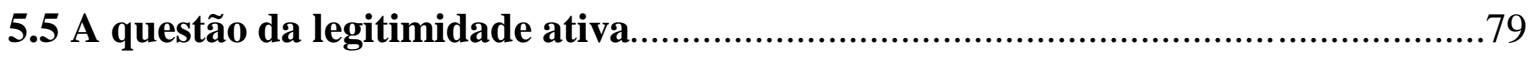

5.6 A necessidade da produção da prova pericial e da oitiva pessoal do

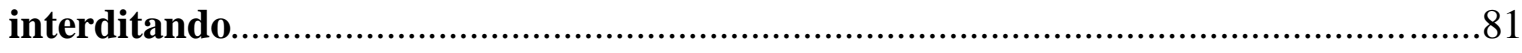

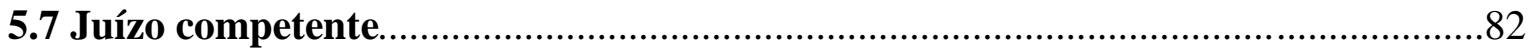

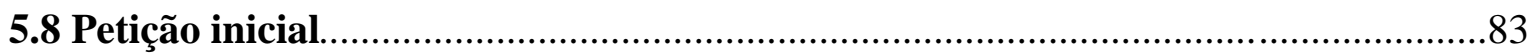

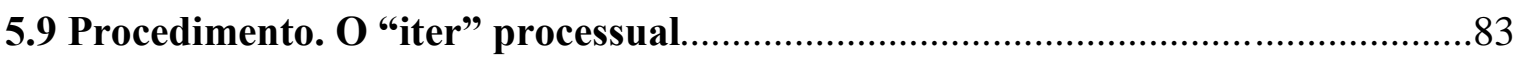

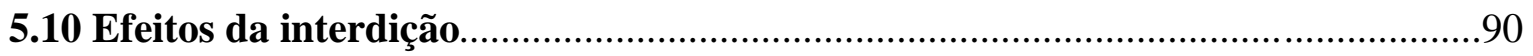

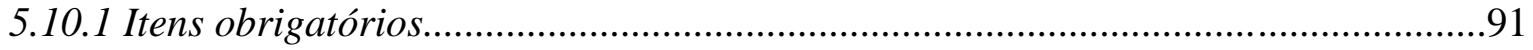

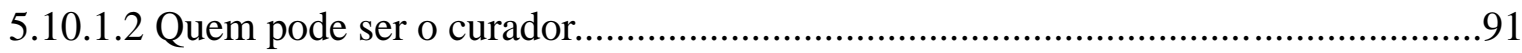

5.10.1.3 Divergências entre curador e curatelado.........................................................92

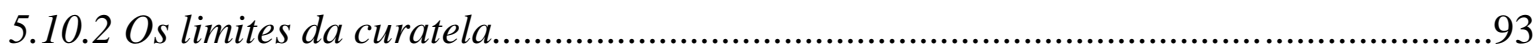


5.10.3 Inscrição da curatela no Registro Civil.

5.10.4 Sobre os atos que o pródigo poderá praticar, e aqueles que o decreto de interdição o impedem de praticar. .95

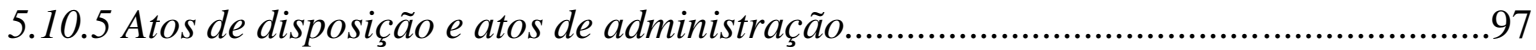

5.10.6 Impedimento ao exercício de profissão ligada ao comércio......................................98

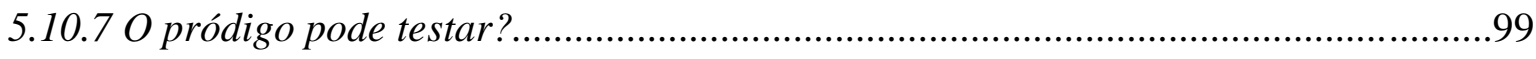

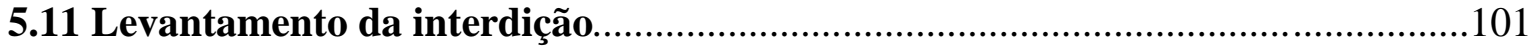

6 A TEORIA dO NEGÓCIO JURÍdICO E O PRÓdIGO .....................................105

6.1 Introdução. Breve apanhado histórico do tema no direito estrangeiro.................105

6.2 A Teoria do Negócio Jurídico no Direito brasileiro........................................... 106

6.3 A Teoria do Negócio Jurídico e a legislação brasileira contemporânea................108

6.4 O negócio jurídico e o ato jurídico. O elemento "vontade" no negócio jurídico.

6.5 Os requisitos: existência, validade e eficácia; a importância da capacidade do agente.

7 BREVES CONSIDERAÇÕES SOBRE O DIREITO DO CONSUMIDOR. O

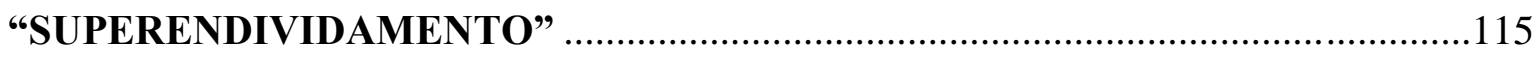

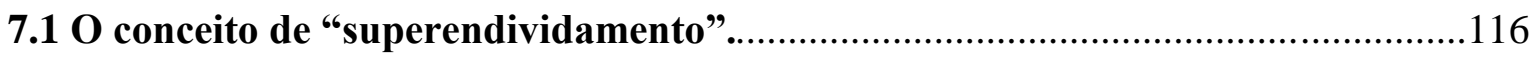

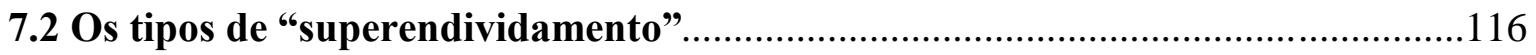

$7.3 \mathrm{O}$ "superendividamento" passivo e a conjuntura econômica...............................118

7.4 "Superendividamento" e prodigalidade...........................................................119

7.5 As soluções para cada caso. Breve análise da jurisprudência sobre o

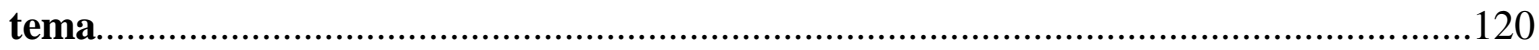

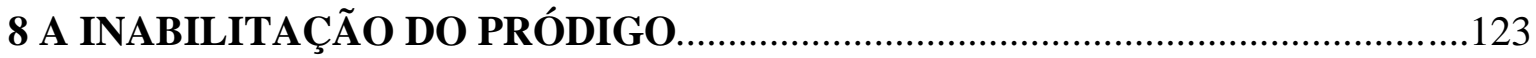

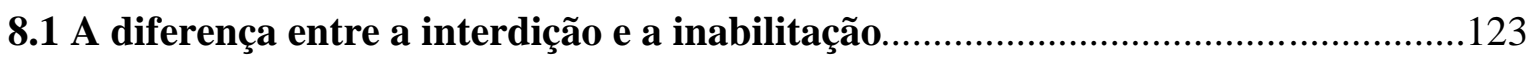

8.20 procedimento na interdição e na inabilitação..............................................125

8.3 A introdução do instituto da inabilitação no Direito Civil brasileiro....................127

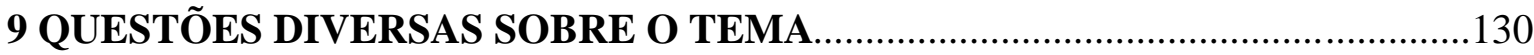

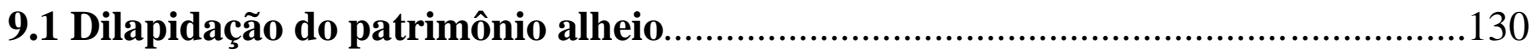


9.2 Reflexos no regime matrimonial de comunhão de bens.....................................131

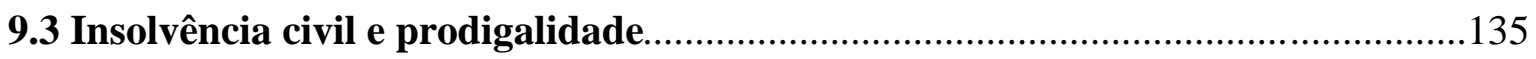

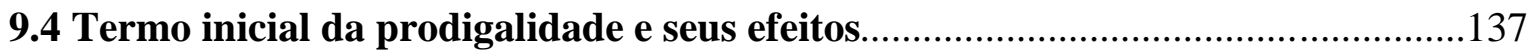

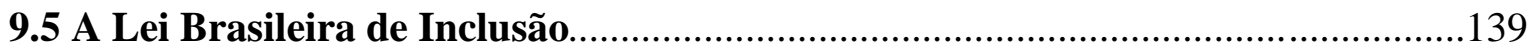

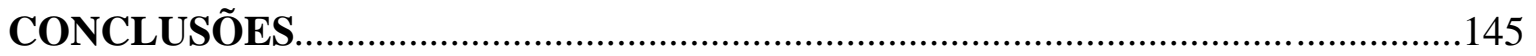

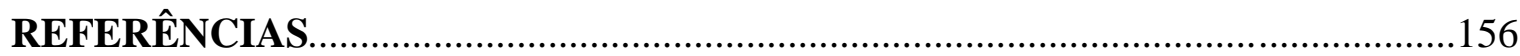




\section{INTRODUÇÃO}

O presente estudo visa analisar a questão do pródigo, perante o moderno Direito Civil brasileiro, em especial nesta fase de transição, em que a sociedade brasileira recebe não apenas um novo Código Civil, mas também um novo Código de Processo Civil e também o denominado Estatuto da Pessoa com Deficiência (Lei n ${ }^{\circ} 13.146$, de 6 de julho de 2015).

Levando-se em conta o fato de que as transformações pelas quais passa a sociedade são responsáveis, da mesma forma, pelas alterações verificadas no ordenamento jurídico que rege as relações entre os membros dessa sociedade, questiona o presente trabalho da necessidade, entre outros assuntos reputados pertinentes, da manutenção do pródigo entre os chamados relativamente incapazes, para efeito de limitar sua capacidade jurídica.

O novo Código Civil, de 2002, assim o faz, mantendo o pródigo como uma das pessoas consideradas como relativamente incapazes, à guisa do que fazia o Código Civil de 1916. Contudo, há ordenamentos jurídicos de outros países que procedem diferentemente.

Também procurar-se-á analisar se, efetivamente, existe um problema, por determinada pessoa gastar sua fazenda desmesuradamente. Para a sociedade, para o comércio, de forma geral, não chega a ser mais interessante um consumidor que gaste bastante? E não se pode deixar de consignar, já ab initio, que o pródigo, por ser como é, dificilmente oferece perigo físico a quem quer que seja; malgrado seja o seu problema encarado, frequentemente, sob o ponto de vista psiquiátrico, não se trata de pessoa que oferece perigo à sociedade; raramente são pessoas de temperamento violento. Ao contrário; centra-se sua excentricidade na generosidade excessiva, no descontrole dos gastos.

Destarte, buscar-se-á, inicialmente, definir o que é o pródigo; e não apenas perante o Direito, mas também, dentro das limitações presumíveis, sob o aspecto médicopsiquiátrico.

Igualmente buscar-se-á efetuar um apanhado da matéria nos períodos de précodificação do Direito Civil, verificando-se como foi tal tipo de pessoa visto, através dos tempos, pelas leis vigentes. 
Em seguida, serão feitas breves considerações sobre o direito estrangeiro; ou seja, verificar-se-á quais ordenamentos jurídicos apresentam solução assemelhada à nossa, e quais apresentam-se diferentes, enfocando a questão sob outro ângulo.

Por fim, chegaremos ao Direito Civil brasileiro, analisando-se os textos do passado, até o momento presente, dando-se atenção não apenas à doutrina, como também à jurisprudência de nossas Cortes, no trato da matéria.

Importante, outrossim, que se analise o procedimento de interdição, constante do novo Código de Processo Civil, o qual veio a revogar disposições do Código Civil de 2002, especificamente no que toca ao mencionado procedimento (o art. 1072 do novo CPC revoga, entre outros, os arts. 1768 a 1773 do Código Civil), havendo, inclusive, recente polêmica com a introdução do referido Estatuto da Pessoa com Deficiência (EPD), que, entrando em vigor quase ao mesmo tempo que o novo CPC, também introduziu novidades nessa área.

A partir da vigência do mencionado Estatuto, também conhecido como Lei Brasileira da Inclusão (LBI), instauraram-se diversas polêmicas, inclusive uma referente à continuidade, ou não, do instituto da interdição, havendo autores que questionam da permanência do mesmo, em face da proeminência da curatela da pessoa com deficiência.

Há, ainda, dentro do tema, questões que não podem ser evitadas.

Não se ignora que, malgrado ainda resista a figura do pródigo não apenas no nosso, mas em diversos ordenamentos jurídicos, vários juristas de renome, como Clóvis Beviláqua, Carvalho Santos e outros, defenderam a retirada da prodigalidade como causa de interdição.

Também há quem questione ser o pródigo uma figura à parte no ordenamento jurídico, sendo a prodigalidade um mero sintoma de um problema mental mais grave, o que pode redundar em reconhecimento não de uma incapacidade relativa, mas de uma incapacidade absoluta. Ou, ainda, quem questione o que se quer proteger; se a pessoa do pródigo ou o seu patrimônio, visando-se a defesa da sociedade (ou do Estado), e não do gastador. São questões que não podem ser esquivadas.

Com a análise desses e de outros temas, acredita-se que o presente estudo se revestirá da necessária roupagem científica, para dar ao assunto entelado a mais ampla abordagem possível; tudo com o intuito de melhor servir à comunidade, pela análise mais aprofundada de questão jurídica pouco examinada pelos nossos doutrinadores, de forma geral. 


\section{CONCEITO DE PRÓDIGO}

Antes que se possa enveredar pela análise da matéria, é de se indagar: o que é, afinal, o pródigo? Como conceituá-lo?

Para tal fim, inicialmente, recorrer-se-á aos nossos dicionários, para o conceito mais corriqueiro; em seguida, aos nossos doutrinadores, para o exame jurídico da questão; por derradeiro, aos textos da psiquiatria, para o conceito médico-psiquiátrico do pródigo.

Ainda se observa que, ao oferecer-se o conceito do pródigo sob o aspecto jurídico, serão trazidos à baila os elementos que compõem o referido conceito de prodigalidade.

\subsection{0 conceito léxico}

Em seu dicionário, Aurélio Buarque de Hollanda Ferreira aduz ser o pródigo aquele “que despende com excesso; generoso; dissipador; esbanjador" (1987, p. 983) ${ }^{1}$.

A palavra vem do latim prodigus, que, literalmente, significava "esbanjador".

De Plácido e Silva aduz que o termo pródigo vem de prodigere, que significa gastar desordenadamente, dissipar, desperdiçar. Assim, ele é

[...] o dissipador, o gastador desabusado, ou seja, a pessoa que gasta ou se desfaz de seus haveres ou bens, sem justificativa, desabusada e desordenadamente, em visível ameaça à estabilidade econômica de seu patrimônio ou de sua fortuna.

O pródigo, assim, é aquele que, sem justa razão, esbanja a fortuna, gastando-a inutilmente ou fazendo gastos e despesas insensatas e excessivas, que possam destruir seus haveres.

A qualidade jurídica de pródigo advém, pois, dos gastos desordenados, dos gastos sem finalidade alguma e do desperdício, que possam ameaçar a própria fortuna (2004, p. 1106).

Luciene Felix Lamy lembra, encarando a questão sob um aspecto filosófico, que

\footnotetext{
1 O mesmo autor, em versão mais recente de seu dicionário, oferece a definição de pródigo como sendo o esbanjador, dissipador, fazendo remissão ao verbete liberal, que é definido como amigo de dar, dadivoso, pródigo. O verbo prodigalizar significaria dar com profusão, liberalizar (FERREIRA, Aurélio Buarque de Holanda. Mini Aurélio - O dicionário da língua portuguesa. 6. ed. Paraná: Editora Positivo, 2004, p. 515 e 656).
} 


\section{CONCLUSÕES}

Por fim, é de se oferecer as conclusões referentes ao tema (ao menos, uma parte das muitas questões que aqui foram tratadas), além de se ofertarem algumas sugestões, pondose necessárias questões sobre a matéria. Ou seja; em face da atual sociedade de consumo, existe, ainda, pertinência na manutenção do pródigo entre os relativamente incapazes?

Pois bem.

Ao longo dos muitos anos de vigência das leis civis em nossas terras, a figura do pródigo foi objeto de considerações específicas, como visto na parte histórica deste trabalho. As Ordenações Filipinas trataram do assunto; posteriormente, o Código Civil de 1916 também o fez, incluindo o pródigo entre o rol dos relativamente incapazes. A polêmica em torno do assunto começou a acirrar-se, tendo o próprio autor do projeto do mencionado Código Civil, Clóvis Beviláqua, chegado a aduzir que a prodigalidade poderia ser tratada como alienação mental, caso em que entraria na regra comum; ou, então, não haveria necessidade de constituir-se uma classificação distinta, eis que inexistiria razão plausível para que a mesma fosse ferida com a interdição.

Ao término dos debates, os legisladores decidiram pela manutenção da interdição de forma relativa, com a nomeação de um curador para a administração dos bens do pródigo.

Com a entrada em vigor do novo Código Civil, em 2002, a interdição por prodigalidade permaneceu quase da mesma maneira, restringindo-se relativamente os poderes do indivíduo; verificou-se, no entanto, uma alteração do quadro que antes se tinha, no que diz respeito ao pródigo e às restrições aos seus direitos.

Seguem, assim, aqui, algumas conclusões e sugestões, tiradas do corpo do trabalho até aqui efetuado e exposto.

Sob o ordenamento civil vigente, é cabível concluir-se que o pródigo é um indivíduo (pessoa física), que gasta o seu patrimônio com exorbitância, dissipando-o. Vários autores, não apenas da área jurídica, ligam a prodigalidade à dipsomania (alcoolismo), atrelando-se ainda tal conduta a jogos de azar, apostas em corridas de cavalo e outras atividades do gênero. Os gastos efetuados pelo indivíduo, para que assim possa ser 
qualificado, devem ser incondizentes com os seus rendimentos, consistindo em despesas fúteis e que, em última análise, podem reduzi-lo à miséria. Tais gastos, ainda, devem ser considerados como excessivos e anormais, em conduta conhecida como monomania ou omniomania. Também pode ser considerada como prodigalidade a assunção de enormes dívidas; a administração tola, néscia e descuidada dos negócios, ou seu abandono; a beneficência e caridade excessivas e inoportunas. Devem tais gastos ser efetuados com habitualidade, para que a pessoa que os faz seja taxada de pródigo; gastos meramente ocasionais, ainda que elevados, não bastam para isso.

Cabível anotar-se, outrossim, que o pródigo é quem dissipa a própria fortuna. Lamentavelmente, existem casos em nossos repositórios de jurisprudência que dão conta de pessoas que dilapidam indevidamente o patrimônio alheio (por exemplo, administradores, tutores ou mesmo curadores, entre outros), incorrendo em clara malversação desses fundos. Tal conduta pode não qualificar tais pessoas como pródigos, como foi colocado no corpo deste trabalho, incorrendo quem assim procede em conduta que inclusive pode ser qualificada até como criminosa, dependendo do caso, respondendo no mínimo civilmente perante o prejudicado. Mas, a princípio, descabe falar-se em interdição por prodigalidade nesse caso.

Os elementos da referida prodigalidade seriam os gastos desordenados; a habitualidade dos referidos gastos; a anormalidade dos mesmos e, por fim, a dilapidação de parte importante do patrimônio do pródigo. Outrossim, é desnecessário que se aguarde o comprometimento irreversível do patrimônio da pessoa suspeita de ser pródigo para iniciar-se os procedimentos cabíveis; basta que se constate a existência de despesas injustificadas pelo indigitado pródigo, sendo cabível que se aja preventivamente, para evitar-se mal maior.

A prodigalidade, outrossim, não é uma enfermidade mental. Não é uma entidade nosológica. Ela, como lembram diversos dos autores das diferentes áreas aqui citados, seja da área jurídica, seja da área médica, pode ser um sintoma de uma referida enfermidade, caso em que será a mesma a denominada prodigalidade sintomática. Entretanto, caso não seja ela tal sintoma, por não padecer o pródigo de qualquer doença mental, será a denominada prodigalidade essencial ou pura, que ocorre com indivíduos que tem tal desvio de conduta desassociado de tais enfermidades. 
Quanto a quem pode requerer a interdição do pródigo, vê-se que há um aumento no número de pessoas que podem propor a ação em questão, em virtude da referida prodigalidade. A curatela do pródigo é disciplinada pela regra geral do tema; destarte, deveria a mesma ser requerida com base no disposto nos incisos I a III do artigo 1768 do novo Código; ou seja, pode ser requerida pelos pais ou tutores; pelo cônjuge ou por qualquer parente; ou, ainda, pelo representante do Ministério Público.

Com a entrada em vigor do novo CPC, o art. 1768 do Código Civil foi revogado (juntamente com os arts. 1769 a 1773), passando a matéria a ser regida pelo referido CPC, cujo art. 747 aduz ser cabível o pedido de interdição formulado: I - pelo cônjuge ou companheiro; II - pelos parentes ou tutores; III - pelo representante da entidade em que se encontra abrigado o interditando (o que configura um avanço, na medida em que o indivíduo pode ter sido deixado à própria sorte por familiares desinteressados em seu bemestar); IV - pelo Ministério Público.

Outrossim, como já observado alhures, dado o alargamento do conceito de família, nos dias atuais, é correta a posição do novo CPC ao entender que a mencionada interdição por argumento de prodigalidade poderá vir a ser requerida também por companheira ou companheiro (inciso I), inclusive no que diz respeito às denominadas uniões homoafetivas, que vem sendo reconhecidas como legais e regulares pela doutrina e pela jurisprudência de nossos Tribunais.

De outra banda, é possível concluir-se, na medida em que a interdição por prodigalidade pode ser requerida por qualquer parente, ou, ainda, pelo representante do Ministério Público, que não é mais possível que se continue a aduzir que o conceito de prodigalidade deve ter vinculação específica com a família.

Quanto ao procedimento de interdição, entende-se, pela boa técnica, que deveria ser feita ressalva no parágrafo $1^{\circ}$ do art. 752 do CPC de 2015, para o caso de ser o procedimento em questão movido pelo órgão do Ministério Público, caso em que o mesmo não atuaria como custos legis (eis que o art. 747, IV, prevê a possibilidade de ser o requerimento feito pelo próprio MP, como titular da ação). Nesse caso, inclusive, descaberia a intervenção de outro promotor, a tal título, posto que o Ministério Público, como é sabido, é uno e indivisível.

No que toca ao levantamento da interdição, observa-se que o CPC/2015 limita o rol das pessoas que poderão pleiteá-lo ao próprio interditado, ao seu curador e ao Ministério Público, quando poderia abrir o leque a outras pessoas interessadas, como, por exemplo, o 
cônjuge (no caso deste não ser o referido curador) ou os parentes próximos do interditado, os quais, pela convivência com o mesmo, tivessem a oportunidade de constatar que o estado mental do interditado veio a apresentar melhora, sendo-lhe possível voltar a reger integralmente os atos de sua vida civil. Tal possibilidade deve ser anotada, posto que podem ocorrer casos de conflitos entre o curador e o interditado, ou, ainda, que pessoas bem intencionadas da família percebam a necessidade do fim dessa interdição, não detectado pelo curador. Entende-se ser de bom alvitre que, numa revisão do novo CPC, inclua-se a possibilidade, nesses casos, do cônjuge e de parentes próximos do interditado solicitarem o fim da interdição, o que deve, sempre, passar pelo crivo do Judiciário.

O fundamento da propalada interdição era, até poucos anos, a proteção da família, com a salvaguarda do seu patrimônio, como ocorria no Direito Romano antigo; agora, sob o pálio do novo Código Civil, passou a ser a proteção do indivíduo, do próprio pródigo, o qual vem a ser protegido por meio da interdição - proteção esta de si mesmo, eis que gasta desmedidamente, dissipando a sua fortuna, os seus bens - proteção esta que emana do princípio da dignidade da pessoa humana. Aliás, não é ocioso lembrar-se que a prodigalidade pode levar o indivíduo à indigência; e, nos tempos atuais, com o maciço desemprego causado pela violenta crise econômica pela qual passa o Brasil, o que menos se necessita é de mais indigentes pelas ruas, criando-se as condições para um verdadeiro caos social. A pouca efetividade das políticas públicas para lidar-se com situações que tais infelizmente vem se evidenciando de forma dramática, e o número de desvalidos pelas ruas só faz crescer.

Ainda no que toca à questão do fundamento da curatela do pródigo, é de se trazer à baila a questão do interesse público.

Como observado acima, o País passa por crise econômica extremamente séria, com grande desemprego e consequências sociais imprevisíveis. E, como as políticas públicas adotadas tem se revelado ineficientes para resolver o problema (somente a cidade de São Paulo, atualmente, segundo fontes da Imprensa, apresenta uma população de moradores de rua na casa dos 20.000, o que equivale a uma cidade de pequeno porte), certamente assiste ao interesse público evitar-se que as pessoas que tem alguma condição de vida cheguem à indigência, engrossando as fileiras dos desafortunados que perambulam sem objetivo pelas nossas ruas... 
Destarte, é pertinente concluir-se que existe um tríplice fundamento para a interdição do pródigo; ou seja, além da proteção da família, que continua imprescindível; além da proteção do próprio pródigo, até por razões humanitárias, também é fundamento desse tipo de curatela a proteção do interesse público.

Isso não implicaria em que se descurasse da análise caso a caso, cuja importância avulta, no trato da matéria enfocada, sendo imperioso trazer-se à baila o fato de que $a$ liberdade para a disposição do próprio patrimônio só é admissível na maneira em que o indivíduo tenha condições de expressar a sua vontade.

Se o erro, o dolo e a coação podem causar a nulidade do ato jurídico, por consistirem os denominados vícios da vontade, então da mesma forma a vontade deve se considerar como viciada, na medida em que a pessoa não está no pleno domínio de suas faculdades mentais, o que decerto vicia a sua capacidade jurídica.

No que toca à questão da aferição do estado mental do pródigo, é importante ressaltar-se a preponderância do critério psicopatológico e da prova pericial. Pode haver mero desvio de conduta; mas pode, como já observado, haver anomalia mental, que incide em vício de seu animus para gastar, redundando na incapacidade prevista no Código Civil - o que deve, de sua banda, ser aferido não apenas pelo juiz que analisar o caso, mas por perito capacitado para tanto, de forma que não se incida em arbítrios. Plausível lembrarse, nesse ponto, que a ganância de parentes inescrupulosos pode levar ao ajuizamento de ações que tais, não com o objetivo de proteção do indivíduo, mas por objetivos argentários dissimulados.

Daí a importância de observar-se o critério psicopatológico para a conclusão referente ao real estado mental do interditando.

Ao longo dos muitos anos de vigência do Código Civil de 1916, houve, como já observado alhures, quem combatesse a inclusão do pródigo entre os denominados relativamente incapazes.

Também é de se lembrar que argumentos respeitáveis da psiquiatria apontam nesse sentido, tendo sido afirmado, em tal área, que a prodigalidade é mero sintoma de um estado mental mais grave.

As posições doutrinárias desfavoráveis e a posição de parte da psiquiatria, que entende, no mais das vezes, que não existe uma anomalia mental denominada "prodigalidade", sendo esta um mero sintoma de outras anomalias mentais (várias delas 
podem causar esse sintoma), levariam, também em tese, a se concluir que não seria cabível manter-se a figura do pródigo entre os denominados "relativamente incapazes", referidos no art. $4^{\circ}$ do novo Código Civil, devendo esse "sintoma" ser avaliado dentro de um contexto maior, de verdadeira doença mental, o que leva à interdição total da pessoa que exibe os referidos "sintomas". A situação seria resolvida não com base no art. $4^{\circ}$ do Código de 2002, mas sim com base no art. $3^{\circ}$ do mesmo Código (ao menos, em sua redação préEstatuto da Pessoa com Deficiência...), tornando-se o indivíduo interditado e, por consequência, incapacitado para gerir sua vida civil.

Contudo, como observado no primeiro capítulo desta obra, ao estudar-se o conceito médico-psiquiátrico de prodigalidade, chegou-se à conclusão de que esta efetivamente pode ser um sintoma de uma anomalia mental, mas não necessariamente ela sempre o é.

Há casos e casos, e certamente se verificará a existência, em nossos repositórios de jurisprudência, de casos em que o interditando não apresenta moléstia mental que possa levar à sua interdição total, como se absolutamente incapaz fosse. Seria justo que se procedesse, em casos que tais, a tão grave restrição a seus direitos na esfera civil?

Com tantas possibilidades diferentes de se configurar a anormalidade dos gastos efetuados, inclusive com a administração desleixada do patrimônio, avulta o aspecto importante da análise caso a caso por parte do Poder Judiciário, ao lhe ser submetido pedido de interdição; e, nesses casos individuais, a importância evidente da realização da prova pericial, sendo o interditando examinado por médico psiquiatra habilitado a verificar seu real estado mental e concluir se o mesmo pode ou não continuar a administrar seus bens e gerir a sua vida. Disto, conclui-se que o critério psico-patológico ainda é o mais seguro para se definir quem é ou não é pródigo, e qual o caminho a seguir a partir de então.

No que diz respeito aos atos que o pródigo pode e os que não pode praticar, a interdição do pródigo não o torna pessoa absolutamente incapaz, que depende de seu curador para todos os atos da vida civil. O art. 1782 do Código Civil de 2002, ainda em vigor, aduz que a sua interdição só o privará de, sem curador, emprestar, transigir, dar quitação, alienar, hipotecar, demandar ou ser demandado, e praticar, em geral, os atos que não sejam de mera administração. Ou seja; os atos que o pródigo não poderá praticar sem o auxílio de seu curador são aqueles referentes à gestão de seu patrimônio, ou, sob outro prisma, os denominados atos de disposição, pois, quando assim procede, usualmente os resultados são desastrosos. 
Pode o pródigo praticar, no que diz respeito ao seu patrimônio, apenas os denominados atos de administração, que não comprometam a sua fazenda de maneira a causar o seu empobrecimento. Assim, busca o Código protegê-lo, bem como a seus familiares e a seu patrimônio.

Pode o pródigo, outrossim, malgrado já interditado, praticar os demais atos da vida civil, como contrair matrimônio, divorciar-se, outorgar a emancipação a seus filhos, permitir que estes se casem, etc.; ou seja, pode praticar atos que não impliquem na denominada gestão patrimonial.

Ainda que se tenha essa limitação em mente, admite-se, hodiernamente, que $o$ pródigo pode fazer seu testamento.

Lembra-se, a propósito, que o pródigo pode exercer a sua profissão, ao que é imperioso acrescentar-se que apenas assim pode proceder se essa profissão não é ligada ao comércio, pois não pode ser comerciante, no sentido jurídico do termo.

Também é pertinente lembrar-se que a prodigalidade não se confunde com o "superendividamento", nem tampouco tem a mesma identidade com a denominada insolvência civil, malgrado haja pontos de contato entre os institutos. $\mathrm{O}$ "superendividamento" é instituto do Direito do Consumidor, ainda não tendo sido o mesmo devidamente regulamentado pelo legislador, estando a jurisprudência de nossas Cortes a encontrar soluções para os casos ligados a tal figura jurídica.

Quanto à insolvência civil, ou falência do devedor civil, entende-se existente a mesma toda vez que as dívidas excederem o patrimônio ativo do devedor. Verifica-se o curioso fato de que a mesma continua a ser regida pelas normas do Código de Processo Civil de 1973, em face do disposto no art. 1052 do novo CPC, posto ainda não ter sido editada lei específica que cuide do caso do devedor insolvente. Assim, continuam a aplicar-se, nesse caso, os arts. 786 e 786-A do CPC/1973. Outrossim, ainda que haja semelhanças com a prodigalidade, não se está a tratar, aqui, com pessoa que apresente mero desvio de conduta (prodigalidade essencial ou pura) ou enfermidade mental que tenha a prodigalidade como um de seus sintomas (a prodigalidade sintomática); não se cuida de absoluta ou mesmo relativamente incapaz, mas sim de um mau negociante, que está, apesar disso, na posse de suas faculdades mentais. 
Alguns países de cultura e tradição jurídica próximas do nosso tem, no seu ordenamento jurídico, o instituto da inabilitação do relativamente incapaz. Assim é na Itália, na Argentina e em nosso irmão Portugal. A inabilitação é uma forma mais branda de interdição, aplicável exclusivamente aos relativamente incapazes, bastante assemelhada ao que, em nosso País, denomina-se simplesmente de curatela.

À primeira vista, dir-se-ia que sua introdução em nosso ordenamento jurídico a nada serviria, revestindo-se do caráter de mera alteração cosmética da lei civil referente à matéria.

Acredita-se, no entanto, que a introdução - e aplicação - desse instituto em nosso ordenamento jurídico poderia ter efeitos positivos, na medida em que seriam extremadas as duas situações jurídicas, configurando-se como mais benéfica, sob o prisma psicológico, ao relativamente incapaz, a aplicação de mera inabilitação, com regulamentação própria, diferenciando sua situação do interditado, que sofreria maiores limitações em capacidade jurídica.

No mais, com o abrandamento generalizado da situação dos deficientes, que está a se dar por meio da introdução das normas do EPD, não se vê razão para não se abrandar, também, a situação do pródigo, procedendo-se à mera inabilitação do mesmo, com a fixação pelo magistrado dos limites de sua atuação.

O Estatuto da Pessoa com Deficiência trouxe diversas mudanças em nosso Direito Civil. Concluiu-se, após análise do referido Estatuto e das normas pertinentes, com as alterações efetuadas no Código Civil de 2002, que o pródigo continua sob o regime jurídico anterior, podendo ser interditado, em face de ter a redação do inciso IV do art. $4^{\circ}$ do CC/2002 ter se mantido a mesma, sem quaisquer alterações; desta forma, pertinente aduzir-se que o pródigo apenas se enquadra nas disposições referentes às pessoas com deficiência se a sua prodigalidade for reconhecida como mero sintoma de enfermidade mental de outra natureza. Ou seja; apenas aqueles que apresentam a denominada prodigalidade sintomática devem ser considerados como deficientes; os que apresentam a prodigalidade essencial ou pura, como simples desvio de conduta, não são assim considerados, aplicando-se-lhes as normas constantes do Código Civil, para o fim de interdição dos mesmos.

Outrossim, pertinente lembrar-se que, malgrado as alterações introduzidas pelo mencionado Estatuto, a interdição não desapareceu. Apenas alterou-se a sua perspectiva, 
tornando-se o procedimento mais flexível; o juiz da causa pode ajustá-lo de acordo com as necessidades do interditando.

Uma conclusão desanimadora, no que diz respeito à aplicação do EPD e a matéria ora em comento, foi a de que o pródigo agora encontra-se em situação de desvantagem perante os deficientes (ao contrário do que ocorria antes da entrada em vigor do mencionado Estatuto), pois estes foram praticamente equiparados às pessoas sãs, não mais sendo cabível a interdição dos mesmos, enquanto os pródigos, como dito linhas atrás, ainda estão sujeitos à interdição.

Quanto à manutenção da figura do pródigo em nosso Código Civil , questão esta a que se referiu logo no início deste trabalho, vê-se que, ainda que a assaz referida dissipação de bens seja o quanto basta para que se afirme ser determinado indivíduo um pródigo, no sentido jurídico do termo, indaga-se: há - ou não - um descompasso entre as normas desse instituto e aquelas constantes da Constituição Federal de 1988, que garantem o direito fundamental à inviolabilidade da vida privada (art. $5^{\circ}$, inciso XII) e o respeito à dignidade da pessoa humana (art. $1^{\circ}$, inciso III), como autêntico princípio fundamental da República?

É de se lembrar, a propósito disso, que as instituições de Direito Civil, nas décadas mais recentes, apresentam-se sob o pálio dos princípios e das normas constantes da Constituição Federal, observando-se o que os estudiosos vieram a definir como sendo o fenômeno da constitucionalização do Direito Civil. Tal fato vem mesmo a causar autêntica reconstrução de alguns de seus conceitos.

Assim, seria, em tese, cabível que o instituto da prodigalidade viesse a sofrer influência da direção hermenêutica desse novo status, fato este que poderia conduzir a uma relativização da aplicação das figuras jurídicas do Direito Civil; como a Constituição Federal tem preponderância sobre as normas desse ramo do direito privado, haveria, ainda em tese, a possibilidade de se redesenhar alguns de seus institutos, em especial em face das mudanças sócio-econômicas verificadas na sociedade moderna.

Daí os questionamentos referentes à pertinência da manutenção do pródigo entre os relativamente incapazes, como se deu na abertura deste capítulo, em virtude também da nova feição de consumo.

Outrossim, é imperioso lembrar-se, malgrado a preponderância das normas constitucionais sobre o restante do arcabouço legislativo brasileiro, que a lei deve ser 
aplicada às situações que se lhe antepõem, de acordo com cada caso. Certamente é cabível argumentar-se com a supremacia dos princípios da dignidade da pessoa humana (erigida, como referido, ao status de autêntico princípio constitucional) e da liberdade, no que diz respeito à disposição do próprio patrimônio; contudo, a curatela é igualmente cabível a partir do momento em que tal liberdade torna-se um perigo para a manutenção da referida dignidade da pessoa - além, é claro, da própria sociedade, como referido linhas atrás, que deverá arcar com o custo de manter mais um desvalido que dilapidou seus haveres. Ou seja: limita-se o exercício da liberdade para manter-se a dignidade, quando os dois princípios entram em rota de colisão, o que vem ao encontro da conclusão no sentido de que também é fundamento da curatela do pródigo o interesse público, como visto linhas atrás.

Isso não implicaria em que se descurasse da análise caso a caso, cuja importância avulta, no trato da matéria enfocada, sendo imperioso trazer-se à baila o fato de que $a$ liberdade para a disposição do próprio patrimônio só é admissível na maneira em que o indivíduo tenha condições de expressar a sua vontade.

Por fim, uma observação necessária.

A temperança é, em verdade, o antônimo, o oposto da prodigalidade.

É ela uma das virtudes éticas a que se referiram os filósofos da Antiguidade; mais precisamente, a que consiste no justo uso dos prazeres físicos.

Reconhecendo-se no mundo jurídico a existência da prodigalidade (e limitando-se os direitos dos pródigos) há muitos séculos, é fato que os filósofos bem analisaram o seu extremo oposto, que é a temperança; a virtude ética que coloca acima o princípio racional, e que evita, assim se agindo, que nos falte à mesa o necessário para nossa sobrevivência.

Vivemos tempos diferentes e difíceis; tempos em que os direitos individuais parecem sobrelevar os deveres do cidadão para com a comunidade, para com o interesse público. A própria Constituição Federal de 1988 é pródiga em atribuir incontáveis direitos aos cidadãos brasileiros, em contraposição ao pequeno número de deveres que lhes são impostos, quiçá como produto de uma época em que saía o povo brasileiro de um regime autoritário para um de maior liberdade.

Desaguamos, contudo, por conta da cultura da permissividade que campeia, numa época de culto ao individualismo, aos prazeres imediatos e fáceis, ao hedonismo, à inconsequência das atitudes. É o triunfo do epicurismo, colocando-se de lado a 
temperança, a modéstia, a racionalidade, a prudência. $O$ herói moderno é o imprudente, $o$ ousado; nunca o racional, o modesto, o equilibrado.

Não espanta, assim, que a figura do pródigo continue a obrigatoriamente ocupar os Códigos do mundo afora e os nossos repositórios de jurisprudência, pululando as decisões a respeito da matéria. Não faltam exemplos para o homem médio a respeito do comportamento correto a seguir; falta-lhe, contudo, equilíbrio, maturidade e, sim, temperança para regular sua vida (e a daqueles que dele dependem) e torná-la melhor.

O ser humano continuará a ser o mesmo, até o fim dos tempos. Mas estarão aí o Direito e a lei para levá-lo ao bom caminho, quando tudo o mais falhar. 


\section{REFERÊNCIAS}

ACADEMIA BRASILEIRA DE LETRAS JURÍDICAS. Dicionário Jurídico. J.M. Othon Sidou (org.). Rio de Janeiro: Forense Universitária, 1990.

ABBAGnANO, Nicola. Dicionário de Filosofia. Tradução de Alfredo Bosi. 3. ed. São Paulo: Martins Fontes, 1998.

ALMEIDA, Isadora Heberle. Interdição por prodigalidade: proteção ao patrimônio ou cerceamento à liberdade? 2010.2 Disponível em: <http://www3.pucrs.br/pucrs/files/uni/poa/direito/graduacao/tcc/tcc2/trabalhos2010_2/isad ora_almeida $>$. Acesso em 19.01.2017.

ALVES, Jones figueiredo. DELGADO, Mário Luiz. Código Civil Anotado. São Paulo: Método, 2005.

ALVES, José Carlos Moreira. Direito Romano. 4. ed. Rio de Janeiro: Forense, 1978, v. 1.

ALVIM, J. E. Carreira. Interdição e Curatela de Interditos. Curitiba: Juruá, 2013.

ANDRADE NETO, Carlos Gonçalves de. O pródigo e a dignidade humana no Direito Civil. 2003. Disponível em: <http://jus.com.br/artigos/4116/0-prodigo-e-a-dignidadehumana-no-direito-civil $>$. Acesso em: 19.01.2017.

ARDENGHY DOS SANTOS, Cláudio Sinoé. Superendividamento: a fragilidade do consumidor. $2005 . \quad$ Disponível em: <https://www.boletimjuridico.com.br/doutrina/artigo/924/superendividamento-fragilidadeconsumidor >. Acesso em: 05.03.2017.

ARRUDA, Roberto Thomaz. Introdução à Ciência do Direito. 1. ed. São Paulo: Edição Universitária de Direito - LEUD, 1987.

ASCENSÃO, José de Oliveira. Direito Civil. 3. ed. São Paulo: Saraiva, 2010. 
ASSUNÇÃO, Alexandre Guedes Alcoforado. Código Civil comentado. Coordenação de Regina Beatriz Tavares da Silva. São Paulo: Saraiva, 2012.

AZEVEDO, Álvaro Villaça. Teoria Geral do Direito Civil - Parte Geral. São Paulo: Atlas, 2012.

AZEVEDO, Antonio Junqueira de. Negócio Jurídico. Existência, Validade e Eficácia. 4. ed. $13^{\mathrm{a}}$ tiragem. São Paulo: Saraiva, 2017.

BERNARDI, Lúcia Maria. O Curador Especial no Código de Processo Civil. 2. ed. Rio de Janeiro: Forense, 2.002.

BEVILÁCQUA, Clóvis. Teoria Geral do Direito Civil. Campinas: Servanda, 2007.

B.G.B. (Bürgerliches Gesetzbuch): Código Civil Alemão. Traduzido por Souza Diniz. Rio de Janeiro: Distribuidora Record Editora, 1960.

BIBLIA, Português. A Bíblia Sagrada. Tradução na Linguagem de hoje. $1^{\text {a }}$ ed., São Paulo: Sociedade Bíblica do Brasil, 1988.

BICALHO, Clóvis Figueiredo Sette; CORRÊA-LIMA, Osmar Brina. Loucura e prodigalidade à luz do Direito e da Psicanálise. Revista de Informação Legislativa do Senado Federal, v. 30, n. 118, p. 363-388, abr./jun.1993.

BITTAR, Carlos Alberto. O Direito Civil na Constituição de 1988. 1. ed. São Paulo: Revista dos Tribunais, 1990. . Os direitos da personalidade. $4^{\mathrm{a}}$ ed. Rio de Janeiro: Forense Universitária, 2.000.

BOMFIM, Silvano Andrade do. Prodigalidade. In: LAGRASTA NETO, Caetano; SIMÃO, José Fernando (Coord.). Dicionário de Direito de Família. São Paulo: GEN/Atlas, 2015, v.2, p. 843-848.

BONFANTE, Pietro. Corso di Diritto Romano. Milano: Dott. A. Giuffrè - Editore, 1963, v. primo: Diritto di Famiglia. Ristampa correta dela I edizione. 
. Istituzioni di Diritto Romano. 5. edizione. Milano: Casa Edittrice Dottor Francesco Vallardi, 1917.

BRASIL. Código Civil Brasileiro, 1916. São Paulo: Rideel, sem data.

BRASIL. Código Civil Brasileiro (Lei n. 10.406, de 10.01.2002). São Paulo: Atlas, 2002.

BRASIL. Código Civil Brasileiro (Lei n. 10.406, de 10.01.2002). 24. ed. São Paulo: Saraiva, 2018.

BRASIL. Código de Processo Civil, 1973. 12 ed. São Paulo: Saraiva, 2006.

BRASIL. Constituição da República Federativa do Brasil. 28. ed. São Paulo: Atlas, 2007.

BRASIL. Consolidação das Leis Civis (de Augusto Teixeira de Freitas). Rio de Janeiro: B. L. Garnier Livreiro Edictor do Instituto Histórico, 1876. v. I e II. Obra fac-similar. Brasília: Conselho Editorial do Senado Federal, 2003.

BRASIL. Decreto Legislativo n. 186/2008. Convenção sobre os Direitos das Pessoas com Deficiência e de seu Protocolo Facultativo. Disponível em: <http://www.planalto.gov.br/ccivil_03/_ato2007-2010/2009/decreto/d6949.htm>. Acesso em: 05.03.2018.

BRASIL. Lei n. 13.146, de 08 de julho de 2015. Estatuto da Pessoa com Deficiência (Lei Brasileira de Inclusão). Vade Mecum (compacto). Saraiva: 17a edição, São Paulo, 2017.

BRASIL. Novo Código de Processo Civil, 2015. 2.ed. Saraiva: São Paulo, 2016.

BRITO, Rodrigo Toscano de. Regime de bens. In: LAGRASTA NETO, Caetano; SIMÃO, José Fernando (Coord.). Dicionário de Direito de Família. São Paulo: GEN/Atlas, 2015, v. 2, p. 871-877.

BUENO, Cássio Scarpinella. Novo Código de Processo Civil anotado. 2. ed. São Paulo: Saraiva, 2016.

BURNS, Edward McNall. História da Civilização Ocidental. Tradução de Lourival Gomes Machado, Lourdes Santos Machado e Leonel Vallandro 2. ed. $11^{\mathrm{a}}$ reimpressão. Porto Alegre: Globo, 1971. v. I. 
CASTEX, Mariano N. Insania e Inhabilitación. Medicina y Psicopsiquiatría Forense. Buenos Aires: Ad-Hoc, 2009. v. VII.

CASTRO, José Manuel Pedreira. El Código Civil através de la Jurisprudencia. Madrid: Librería General de Victoriano Suárez, sem data. Tomo I.

CASTRO FILHO, José Olympio de. Comentários ao Código de Processo Civil. 5. ed. Rio de Janeiro: Forense, 2004. v. X.

CHAVES, Antônio. Lições de Direito Civil. São Paulo: Editora da Universidade de São Paulo e José Bushatsky Editor, 1972, v. III: Parte Geral.

. Tratado de Direito Civil. 2. ed. São Paulo: Revista dos Tribunais, 1993, v.5. Tomo 2: Direito de Família.

CODE CIVIL. Nouvelle édition. Issy-les-Molineaux: Prat Éditions, 2009.

CODIGO CIVIL DE LA REPUBLICA ARGENTINA (con las notas de Velez Sarsfield). Buenos Aires: Victor P. de Zavalía Editor, 1978.

CODICE CIVILE. Milano: Dott. A. Giuffrè Editore, 1993.

CÓDIGO CIVIL ESPAÑOL. Undécima edición, preparada por José Antonio Pajares Giménez. Madrid: Editorial Civitas, 1988.

CÓDIGO CIVIL PORTUGUÊS. Texto revisto, prefácio e notas de Adriano Paes da Silva Vaz Serra. Coimbra: Atlântida Editora, S.A.R.L., 1967.

CÓDIGO DE HAMURABI. CÓDIGO DE MANU (Livros Oitavo e Nono). LEI DAS XII TÁBUAS. $3^{\mathrm{a}}$ ed. revista. São Paulo: EDIPRO, 2011.

COELHO, Fábio Ulhoa. Código Comercial e Legislação Complementar Anotados. 1. ed. São Paulo: Saraiva, 1995. 
CORREIA, Alexandre; SCIASCIA, Gaetano. Manual de Direito Romano. Série "Cadernos Didáticos". Guanabara: Livros Cadernos Ltda., sem data.

CRETElLA JÚNIOR, José. Direito Romano Moderno. 2. ed. Rio de Janeiro: Forense, 1980.

CROCE, Delton; CROCE JÚNIOR, Delton. Manual de Medicina Legal. 6. ed. São Paulo: Saraiva, 2009.

DINIZ, Maria Helena. Curso de Direito Civil Brasileiro. 31. ed. São Paulo: Saraiva, 2014, v.1: Teoria Geral do Direito Civil.

DONIZETTI, Elpidio; QUINTELLA, Felipe. Curso Didático de Direito Civil. 3. ed. São Paulo: Atlas, 2014.

FEINBERG, Joel. Harm to Self. The moral limits of the Criminal Law. New York: Oxford University Press, 1986.

FERRAND, Frédérique. Droit Privé Allemand. Paris: Dalloz, 1997.

FERREIRA, Aurélio Buarque de Holanda. Mini Aurélio - O dicionário da língua portuguesa. 6. ed. Paraná: Editora Positivo, 2004.

. Pequeno Dicionário Brasileiro da Língua Portuguesa. 11. ed. Com a assistência de José Baptista da Luz. Rio de Janeiro: Civilização Brasileira S.A., 1987.

FRANÇA, R. Limongi. Instituições de Direito Civil. 2a ed. São Paulo: Saraiva, 1991.

. O Direito, a Lei e a Jurisprudência. São Paulo: Revista dos Tribunais, 1974.

FRANKLIN, Reginaldo. Estudo médico-legal da prodigalidade. 2014. Disponível em: <http://reginaldofranklin.com.br/estudo-medico-legal-da-prodigalidade/>. Acesso em 22.06.2017. 
GAGLiAnO, Pablo Stolze. É o fim da interdição? Publicado por Flávo Tartuce. 2015. Disponível em: <http://flaviotartuce.jusbrasil.com.br/artigos/304255875/e-o-fim-dainterdicao-artigo-de-pablo-stolze-gagliano>. Acesso em 28.09.2018.

GHERSI, Carlos Alberto. Derecho Civil - Parte General. 2. edición actualizada y ampliada. Ciudad de Buenos Aires: Editoreal Astrea (de Alfredo y Ricardo Depalma), 1999.

GHIRARDI, Juan Carlos. Inhabilitación Judicial. 2. edición actualizada y ampliada. Ciudad de Buenos Aires: Editoreal Astrea (de Alfredo y Ricardo Depalma), 1991.

GILISSEN, John. Introdução Histórica ao Direito. Tradução de A. M. Hespanha e L. M. Macaísta Malheiros. 8. ed. Lisboa: Fundação Calouste Gulbenkian, 2016.

GONÇALVES, Carlos Roberto. Direito Civil - Parte Geral. 1. ed. São Paulo: Saraiva, 1997.

GONÇALVES, Marcus Vinicius Rios. Direito Processual Civil esquematizado. 7. ed. São Paulo: Saraiva, 2016.

GRECO FILHO, Vicente. Direito Processual Civil Brasileiro. 22. ed. São Paulo: Saraiva, 2013.

INSTITUCIONES DE JUSTINIANO. Tradução de Melquíades Pérez Rivas. 1. ed. Buenos Aire: Editorial Heliasta S. R. L., 1944, 2005.

KRAUSE, Harry D. Family Law in a nutshell. Third edition. St. Paul, Minnesota: West Publishing Co, 1995.

LAMY, Luciene Felix. A volta do filho pródigo. Carta Forense. São Paulo, p. B17, ago. 2017.

LE SCORNET, Laure. La Protection des Personnes Vulnérables. Premier edition. Paris: Le Particulier Editions, 2011.

LEITE, Flávia Piva Almeida; RIBEIRO, Lauro Luiz Gomes; COSTA FILHO, Waldir Macieira. Comentários ao Estatuto da Pessoa com Deficiência. Comentário de Waldir Macieira da Costa Filho. São Paulo: Saraiva, 2016, p. 367-368. 
LIMA, João Batista de Souza. As mais antigas normas de Direito. 2. ed. Rio de Janeiro: Forense, 1983.

LIMA, Pires de; VARELA, Antunes. Código Civil Anotado. 4. ed. revista e actualizada. Coimbra: Coimbra Editora Limitada, 1987. v. I: $\operatorname{artigos} 1^{\circ}$ a $761^{\circ}$.

LOBO, Paulo. Com avanços legais, pessoas com deficiência mental não são mais incapazes. 2015. Disponível em: https://www.conjur.com.br/2015-ago-16/processofamiliar-avancos-pessoas-deficiencia-mental-nao-sao-incapazes> Acesso em 13/11/2018.

LOUREIRO, Francisco Eduardo. Interdição. In: LAGRASTA NETO, Caetano; SIMÃO, José Fernando (Coord.). Dicionário de Direito de Família. São Paulo: GEN/Atlas, 2015. v. 2. p. $552-554$.

LOPES, Miguel Maria de Serpa. Curso de Direito Civil. 1. ed. Rio de Janeiro: Livraria Freitas Bastos S.A.,1953. v. I: Introdução e Parte Geral.

MACHADO, Costa; CHINELlATO, Silmara Juny. Código Civil interpretado. Comentários de Silmara Juny Chinellato e Ricardo A. Gregório. 11. ed. São Paulo: Manole, 2018. p. 43, 1566 e 1570.

MALUF, Carlos Alberto Dabus; MALUF, Adriana Caldas do Rêgo Freitas Dabus. Direito de Família. 2. ed. São Paulo: Saraiva, 2016.

. Direito de Família. 3. ed. São Paulo: Saraiva, 2018. . Introdução ao Direito Civil. São Paulo: Saraiva, 2017.

MARANHÃO, Odon Ramos. Curso Básico de Medicina Legal. 3. ed. São Paulo: Revista dos Tribunais, 1984.

MARCATO, Antonio Carlos. Procedimentos Especiais. 1. ed. São Paulo: Revista dos Tribunais, 1986. 
MARCHIORI NETO, Daniel Lena. Contribuição ao estudo da prodigalidade. 2004. Disponível em: 〈http://jus.com.br/artigos/4863/contribuicao-ao-estudo-da-prodigalidade>. Acesso em: 19.01.2017.

MARKY, Thomas. Curso Elementar de Direito Romano. 7. ed. São Paulo: Saraiva, 1994.

MARQUES, Cláudia Lima. Contratos no Código de Defesa do Consumidor. 4ª ed. São Paulo: Revista dos Tribunais, 2002.

Sugestões para uma lei sobre o tratamento do superendividamento de pessoas físicas em contratos de crédito ao consumo. Revista de Direito do Consumidor, n. 55. São Paulo: Revista dos Tribunais, 2005.

MELlO, Marcos Bernardes de. Teoria do Fato Jurídico - Plano da validade. 3. ed. São Paulo: Saraiva, 1999.

MINIDICIONÁRIO SOARES AMORA DA LÍNGUA PORTUGUESA. Afonso Telles Alves, org. $7^{\text {a }}$ ed., São Paulo: Saraiva, 2000.

MIRANDA JUNIOR, Darcy Arruda. Curso de Direito Comercial. 4. ed. São Paulo: José Bushatksy Editor, 1978. v. 2: Sociedades Comerciais.

MONTEIRO, Washington de Barros. Curso de Direito Civil. 39. ed. (atualizada por Ana Cristina de Barros Monteiro França Pinto). São Paulo: Saraiva, 2003. V. 1: Parte Geral.

MONTEIRO, Washington de Barros; PINTO, Ana Cristina de Barros Monteiro França. Curso de Direito Civil. 45. ed. São Paulo: Saraiva, 2016. v. 1: Parte Geral.

MONTEIRO, Washington de Barros; SILVA, Regina Beatriz Tavares da. Curso de Direito Civil. 42. ed. Saraiva: São Paulo, 2013. v. 2: Direito de Família.

MOTTA, Carlos Dias. Regime de bens: princípios. In: LAGRASTA NETO, Caetano; SIMÃO, José Fernando (Coord.). Dicionário de Direito de Família. São Paulo: GEN/Atlas, 2015. v. 2.

NAPOLI, Emilio Vito. L'Inabilitazione. Prima edizione. Milano: Dott. A. Giuffré Editore, 1985.

NATIONAL ENQUIRER (revista). Vol. 84, n. 1, janeiro de 2009. 
NERY JÚNIOR, Nelson; NERY, Rosa Maria Andrade. Código Civil Anotado e legislação extravagante. 2. ed. São Paulo: Revista dos Tribunais, 2003.

. Código Civil Comentado. $8^{\mathrm{a}}$ ed., São Paulo: Revista dos Tribunais, 2011.

2016.

. Código de Processo Civil comentado. 16. ed. São Paulo: Revista dos Tribunais,

OLIVEIRA, Júlio Aguiar de. A prodigalidade e o Direito. Sem data. Disponível em: <http://www.hottopos.com/videtur31/julio1.htm>. Acesso em: 19.01.2017.

PAIVA, André Luis Parizio Maia. Necessária diferenciação entre pródigos e superindividados em face dos tratamentos jurídicos correspondentes. 2010. Disponível em: < https://jus.com.br/artigos/14906>. Acesso em: 17.07.2017.

PALOMBA, Guido Arturo. Tratado de Psiquiatria Forense Civil e Penal. 1. ed. São Paulo: Atheneu, 2003.

PEREIRA, Caio Mário da Silva. Instituições de Direito Civil. 19. ed. Rio de Janeiro: Forense, 1999. v. 1: Teoria Geral do Direito Civil. de Família.

Instituições de Direito Civil. 11. ed. Rio de Janeiro: Forense, 1999. v. V: Direito

PONTES DE MIRANDA, Francisco Cavalcanti. Tratado de Direito Privado. Parte Geral. 4. ed. 2 tiragem. São Paulo: Revista dos Tribunais, 1983. Tomo I (Introdução. Pessoas físicas e jurídicas).

RÁO, Vicente. Ato Jurídico. 3. ed. anotada e atualizada por Ovídio Rocha Barros Sandoval. São Paulo: Revista dos Tribunais, 1994.

RODRIGUES, Silvio. Direito Civil. 32. ed. São Paulo: Saraiva, 2.002. v. 1: Parte Geral.

. Direito Civil. 27. ed. São Paulo: Saraiva, 2002. v. 6: Direito de Família. 
SANTOS, Claudio Sinoé Ardenghy dos. Superendividamento: a fragilidade do consumidor. Disponível em: <https://www.boletimjuridico.com.br/doutrina/artigo/924/superendividamento-fragilidadeconsumidor>. Acesso em 08/10/2018.

SILVA, De Plácido e. Vocabulário Jurídico. 25. ed. Rio de Janeiro: Forense, 2004.

SIMÃO, José Fernando. Estatuto da Pessoa com Deficiência causa perplexidade (Parte 1). Disponível em https://www.conjur.br/2015-ago-06/jose-simao-estatuto-pessoa-deficienciacausa-perplexidade. Acesso em 08/10/2018.

TARTUCE, Flávio. Alterações do Código Civil pela Lei 13.146/2015 (Estatuto da Pessoa com Deficiência). Repercussões para o Direito de Família e Confrontações com o Novo CPC. Parte II. 2015.2 Disponível $<$ https://www.migalhas.com.br/FamiliaeSucessoes/104,MI225871,51045Alteracoes+do+Codigo+Civil+pela+lei+131462015+Estatuto+da+Pessoa+com> Acesso em 11/09/2018.

. Direito Civil. 13. ed. Rio de Janeiro: GEN/Forense, 2018. v. 5: Direito de Família.

TEPEDINO, Gustavo; BARBOZA, Heloisa Helena; MORAES, Maria Celina Bodin de. Código Civil interpretado conforme a Constituição da República. Rio de Janeiro: Renovar, 2004. v. I: Parte geral e obrigações.

TRABUCCHI, Alberto. Istituzioni di Diritto Civile. Trentesima terza edizione aggiornata com le riforme legislative e com la giurisprudenza. Padova: CEDAM - Casa Editrice Dott. Antonio Milani, 1992.

TRINDADE, Jorge. Manual de Psicologia Jurídica para operadores do Direito. 4. ed. Porto Alegre: Livraria do Advogado, 2010.

VANNIER, Patricia. Fiches de Droit des Personnes. Premier édition. Paris: Ellipses Édition Marketing S.A., 2009.

VELOSO, Zeno. Comentários ao Código Civil. Coord.: AZEVEDO. Antônio Junqueira de. São Paulo: Saraiva, 2003. v. 21: Parte Especial do Direito das Sucessões.

VENOSA, Sílvio de Salvo. Direito Civil. 5.ed. São Paulo: Atlas, 1999. v. 1: Teoria Geral. 
. Direito Civil. 3. ed. São Paulo: Atlas, 2003. v. 6: Direito de Família.

VIEIRA, Patricia Ruy. A interdição no direito civil brasileiro. Revista dos Tribunais, ano 93, p. 93-116, ago. 2004, v. 826.

VON TUHR, A. Derecho Civil. Traducción directa del alemán por Tito Raya. Madrid/Barcelona, Marcial Pons: Ediciones Juridicas y Sociales. S.A., 1999. v. 1(2): Las personas.

WALD, Arnoldo. Curso de Direito Civil Brasileiro: Introdução e Parte Geral. Com a colaboração de ÁLVARO VILLAÇA DE AZEVEDO. 8. ed. São Paulo: Revista dos Tribunais, 1995. 